\title{
KADAR TIMBEL DALAM DARAH SISWA SEKOLAH DASAR DI SEKITAR PELEBURAN AKI BEKAS DI KABUPATEN TANGERANG DAN LAMONGAN
}

\author{
BLOOD LEAD LEVELS OF ELEMENTARY STUDENTS AROUND USED \\ BATTERY SMELTERS IN TANGERANG AND LAMONGAN REGENCY
}

Bambang Hindratmo, Rizqika Rahmani, dan Rita(1)

(Diterima tanggal 1 April 2018, Disetujui tanggal 2 Juli 2018)

\begin{abstract}
ABSTRAK
Logam Timbel $(\mathrm{Pb})$ merupakan salah satu logam berat yang dimanfaatkan secara luas dalam industri aki. Aki timbel yang sudah tidak terpakai masih memiliki nilai ekonomis lewat proses peleburan (smelting), namun logam timbel memiliki efek negatif terhadap kesehatan. Paparan timbel dalam darah (BLL/ Blood Lead Level) khususnya pada anak-anak dapat mengakibatkan penurunan tingkat kecerdasan, masalah kesehatan, bahkan berdampak sosial. Untuk mengetahui tingkat pajanan timbel yang dihasilkan pabrik peleburan aki bekas di Kabupaten Tangerang dan Kabupaten Lamongan, dilakukan pengukuran kadar timbel dalam darah siswa Madrasah Ibtidaiyah (MI) Baitussa'adah dan SDN Bulu Tengger yang terletak di sekitar pabrik tersebut. Pengukuran konsentrasi timbel dalam darah dilakukan dengan menggunakan Lead Care Portable Analyzer. Telah diperoleh rata-rata konsentrasi timbel dalam darah anak-anak MI Baitussa'adah mencapai 32,0 $\mu \mathrm{g} / \mathrm{dL}$, dengan konsentrasi minimum 15,5 $\mu \mathrm{g} / \mathrm{dL}$, konsentrasi maksimum tidak dapat dipastikan karena melampaui batas maksimum deteksi alat ( $65 \mu \mathrm{g} / \mathrm{dL})$. Dari 69 sampel darah anak-anak SDN Bulu Tengger, diketahui rata-rata konsentrasi timbel dalam darah mencapai 11,8 $\mu \mathrm{g} / \mathrm{dL}$, dengan konsentrasi minimum $5 \mu \mathrm{g} / \mathrm{dL}$, dan konsentrasi maksimum 30,8 $\mu \mathrm{g} / \mathrm{dL}$. Nilai tersebut jauh di atas nilai rujukan WHO tahun 1991 dan The Centers for Disease Control and Prevention's (CDC) tahun 2012. Hal ini menunjukkan pajanan timbel dari pabrik peleburan aki bekas sudah sangat membahayakan dan mengancam kesehatan masyarakat sekitar khususnya anak-anak usia sekolah.
\end{abstract}

Kata Kunci : logam timbel, aki bekas, BLL, lead care, anak-anak, smelter

\begin{abstract}
Lead Metal (Pb) is one of the heavy metals widely used in the accumulator (battery) industry. The lead battery that can be recharged is commonly used. The Lead battery consists of two metal plates, $\mathrm{Pb}$ and $\mathrm{PbO}$, which dissolved in $\mathrm{H}_{2} \mathrm{SO}_{4}$. Used Lead batteries still have an economic value by recovering lead through smelting. In addition to these benefits, Lead metal has a negative effect on health. Exposure to Lead in the blood especially in children can lead to decreased levels of intelligence, health problems, and even social impacts. To determine the level of Lead exposure generated by used battery smelters in Tangerang and Lamongan Regency, blood Lead levels in Madrasah Ibtidaiyah (MI) Baitussa' adah and SDN Bulu Tengger students which located around the smelters, were determined. Measurement of Lead concentration in blood was performed using Lead Care Portable Analyzer (ESA Laboratories, Chelmsford, MA, USA). In Tangerang, it was found that the mean BLL was 32,0 $\mu \mathrm{g} / \mathrm{dL}$, with a minimum concentration of 15,5 $\mu \mathrm{g} / \mathrm{dL}$, and a maximum concentration could not be assured since the result was above the instrument's maximum detection limit (65 $\mathrm{g} / \mathrm{dL}$ ). The average value is far above the WHO and CDC (1991) and CDC (2012) threshold for blood lead levels of $10 \mu \mathrm{g} / \mathrm{dL}$ and $5 \mu \mathrm{g} / \mathrm{dL}$ respectively. While in Lamongan, it was determined that the mean BLL was $11,8 \mu \mathrm{g} / \mathrm{dL}$, with a minimum concentration of $5 \mu \mathrm{g} / \mathrm{dL}$, and a maximum concentration of 30,8 $\mu \mathrm{g} / \mathrm{dL}$ This indicates that lead exposure from lead smelters has been very dangerous and threatens the health of surrounding communities, especially school-aged children. Further research is needed in mitigating the impact of lead pollution especially on school-aged children
\end{abstract}

Keywords: lead, used batteries, children, blood lead levels, lead care, smelter 


\section{PENDAHULUAN}

Timbel merupakan salah satu logam berat yang banyak dimanfaatkan dalam industri aki. Timbel dalam aki berfungsi sebagai elektroda positif dan negatif tempat berlangsungnya reaksi reduksi oksidasi (redoks) yang menghasilkan energi listrik. Reaksi redoks yang terjadi dalam aki adalah :

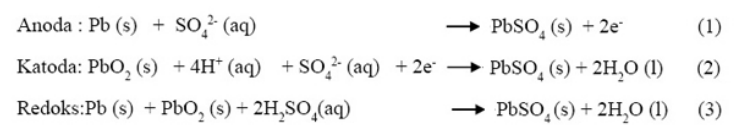

Reaksi redoks tersebut dapat dimuat ulang dengan mengalirkan arus listrik kepada sel aki tersebut. Proses ini akan menghasilkan endapan garam sulfat $\left(\mathrm{PbSO}_{4}\right)$ di kedua lempeng, dan mengurangi performa aki tersebut. Pada ketebalan tertentu deposit ini akan membuat aki tidak dapat dimuat ulang, sehingga aki harus diganti. Aki bekas yang tidak dapat dimuat ulang masih memiliki nilai ekonomis sehingga menjadi buruan pengumpul aki bekas. Lempeng timbel yang terdapat dalam aki bekas dapat didaur ulang melalui proses peleburan dan pemurnian. Pada proses daur ulang inilah terdapat potensi pencemaran lingkungan berupa asap dan debu dari proses peleburan lempeng timbel, limbah cair yang mengandung sulfat dan bau sulfur yang spesifik [1]. Asap dan debu yang mengandung timbel dapat menyebar dan memapar lingkungan, khususnya masyarakat di sekitar pabrik peleburan aki bekas tersebut (smelter). Paparan timbel masuk ke dalam tubuh manusia melalui jalur inhalasi dan terakumulasi dalam darah, jaringan gigi, tulang bahkan rambut [2].

Menurut penelitian WHO 1991, keracunan timbel pada ibu hamil bisa mengakibatkan bayi lahir prematur, keguguran, atau meninggal.
Sedangkan pada anak-anak akan berdampak negatif pada kecerdasan [2]. Center for Disease Control and Prevention (CDC) USA, sebuah instansi pusat pengendalian dan pencegahan penyakit pemerintah Amerika Serikat, tahun 2012 menetapkan batasan baru nilai rujukan konsentrasi timbel dalam darah anak-anak sebesar $5 \mu \mathrm{g} / \mathrm{dL}$, sebelum tahun 2012, sebesar $10 \mu \mathrm{g} / \mathrm{dL}$, di atas nilai tersebut, timbel dapat menimbulkan gangguan kesehatan dan kecerdasan (IQ) [3].

Berbagai sumber pajanan timbel akan masuk kedalam tubuh anak-anak melalui jalur pernapasan, pencernaan dan kontak dengan kulit. Paparan timbel tersebut dapat menyebabkan dampak kesehatan pada anakanak misalnya anemia, perilaku anti sosial, gangguan fungsi ginjal, sulit belajar, tekanan darah dan gangguan kardiovaskular meningkat. Anak menjadi tidak konsentrasi pada pelajaran, IQ turun dratis, gangguan penyakit saraf, hipertensi, ganguan pertumbuhan otak, dan sesak napas [4]. Siswa yang memiliki BLL tinggi mempunyai peluang 3,4 kali untuk memiliki tingkat kecerdasan (majemuk) rendah [13]. Bahkan timbel diketahui dapat mempengaruhi saraf anak-anak sehingga berakibat pada perubahan perilaku sosial pada saat dewasa yang mengarah pada kriminalitas [5]. Menurut ahli kesehatan, masuknya timbel ke dalam darah anak-anak akan langsung menggantikan Hemoglobin ( $\mathrm{Hb}$ ) dalam darah, sedangkan pada orang tua, timbel akan terdeposit ke dalam tulang, sehingga pengujian timbel dalam darah ini lebih tepat dilakukan terhadap anak-anak [2].

Pada penelitian ini, ditentukan kadar timbel dalam darah anak-anak usia sekolah sebagai biomarker paparan timbel pada manusia. 
Selanjutnya, untuk melihat seberapa banyak pajanan tersebut, diukur kadar timbel dalam darah di daerah sekitar pabrik peleburan aki bekas untuk memastikan bahwa di daerah tersebut telah terjadi paparan timbel pada masyarakat khususnya anak-anak.

\section{METODOLOGI}

\section{Lokasi Pengambilan Contoh Uji dan Pemilihan Responden}

Lokasi pengambilan sampel ialah di Desa Kadu, Kecamatan Curug, Kabupaten Tangerang, Provinsi Banten yang berjarak \pm 500 meter dari Kawasan Industri Manis Jaya. Lokasi sampling di Kabupaten Tangerang disajikan pada Gambar 2 dan 3.

Pengambilan sampel juga dilakukan di Desa

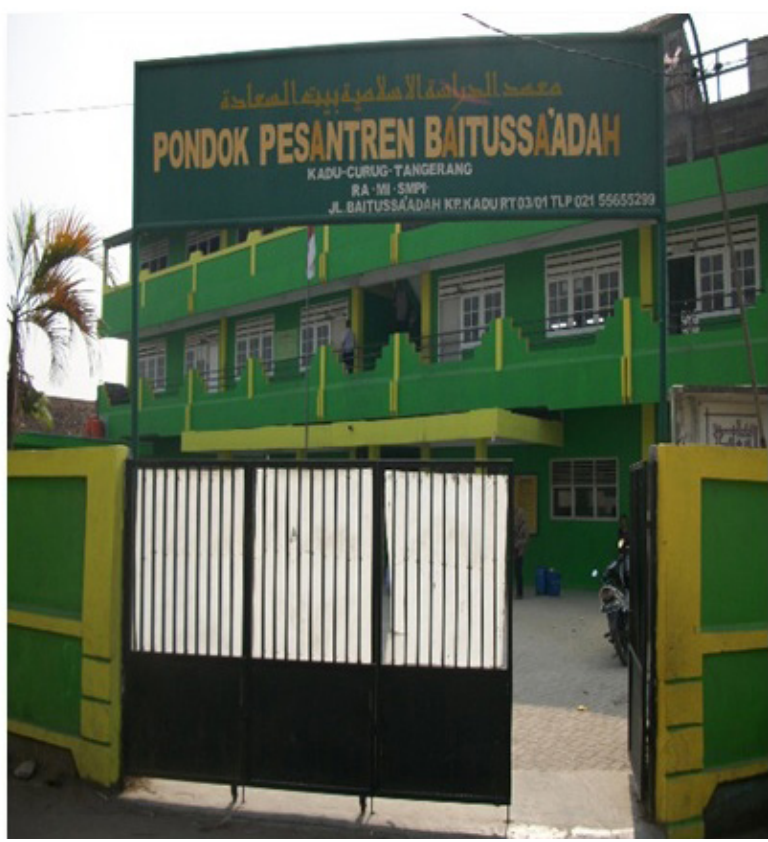

Gambar 2. Lokasi Pengambilan Sampel Darah di Kabupaten Tangerang
Bulu Tengger, Kecamatan Sekaran, Kabupaten Lamongan, Provinsi Jawa Timur yang berjarak $\pm 3 \mathrm{~km}$ dari home industry peleburan aki bekas. Lokasi sampling disajikan pada Gambar 4 dan 5 .

Kriteria pemilihan sampel dilakukan sebagai berikut:

a. Sampel diambil pada anak-anak kelas 2, 3, dan 4 Sekolah Dasar yang telah berdiri dan beraktivitas di Kabupaten Tangerang dan Kabupaten Lamongan;

b. Responden bersedia dan diizinkan orang tuanya untuk berpartisipasi dalam penelitian;

c. Responden dalam keadaan sehat atau telah sembuh dari sakit minimal 7 hari sebelum pengambilan sampel darah dilakukan.

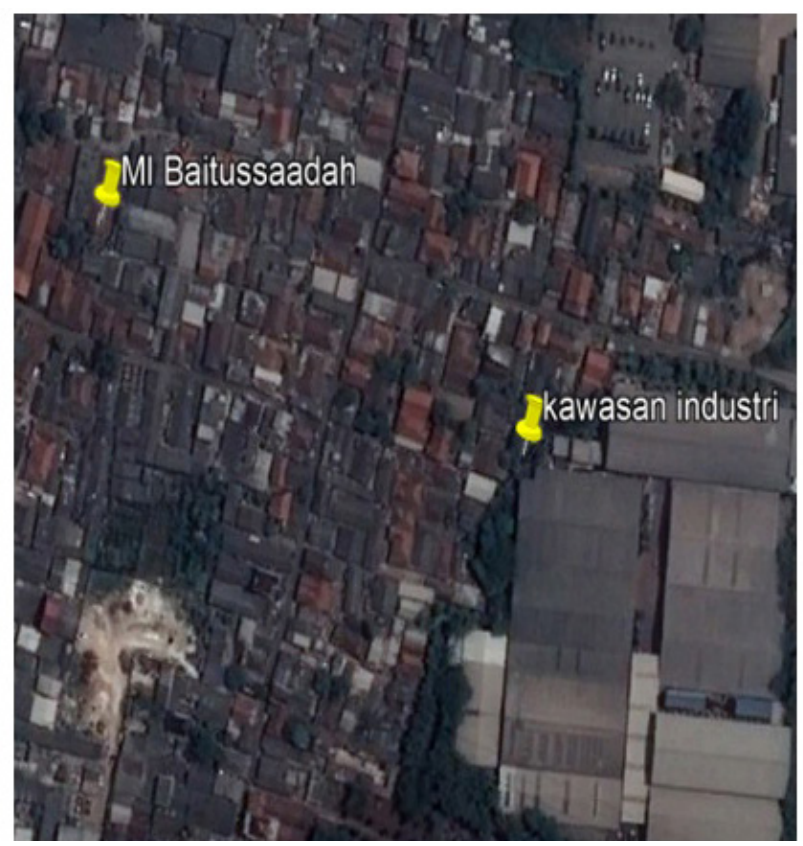

Gambar 3. Lokasi Kawasan Industri Manis Jaya di Desa Kadu, Kabupaten Tangerang 


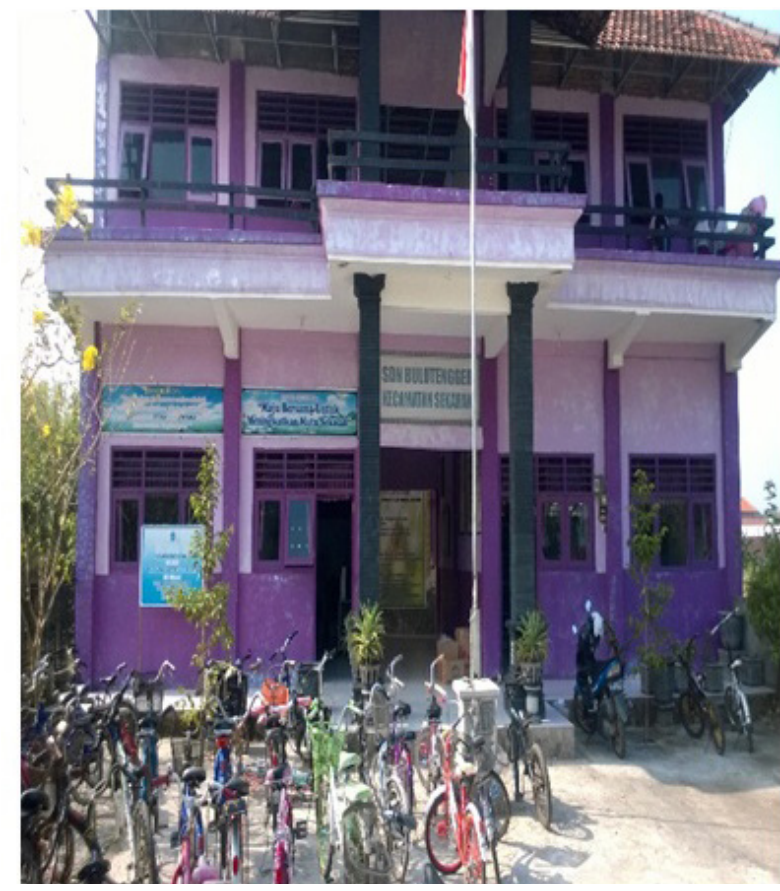

Gambar 4. Lokasi Pengambilan Sampel Darah di Kabupaten Lamongan

\section{Teknik Pengambilan Contoh Uji}

a. Sebelum melakukan pengambilan contoh uji darah anak-anak, tim terlebih dahulu melakukan koordinasi dan sosialisasi mengenai pentingnya kegiatan ini dilakukan, penjelasan mengenai bahaya timbel dan cara penanggulangannya. Sosialisasi dihadiri oleh guru dan orang tua murid. Tujuannya agar kegiatan ini dapat dipahami dan bermanfaat bagi masyarakat, dan anak-anak bersedia dijadikan sebagai responden;

b. Pengisian formulir izin/persetujuan oleh orang tua murid dan formulir yang telah ditandatangani dikumpulkan kembali sebagai bukti kesediaan responden;

c. Tim didampingi oleh dokter dan petugas Puskesmas terdekat menjelaskan prosedur pengambilan contoh uji darah anak-anak;

d. Tim menyiapkan peralatan yang akan digunakan dalam pengambilan contoh

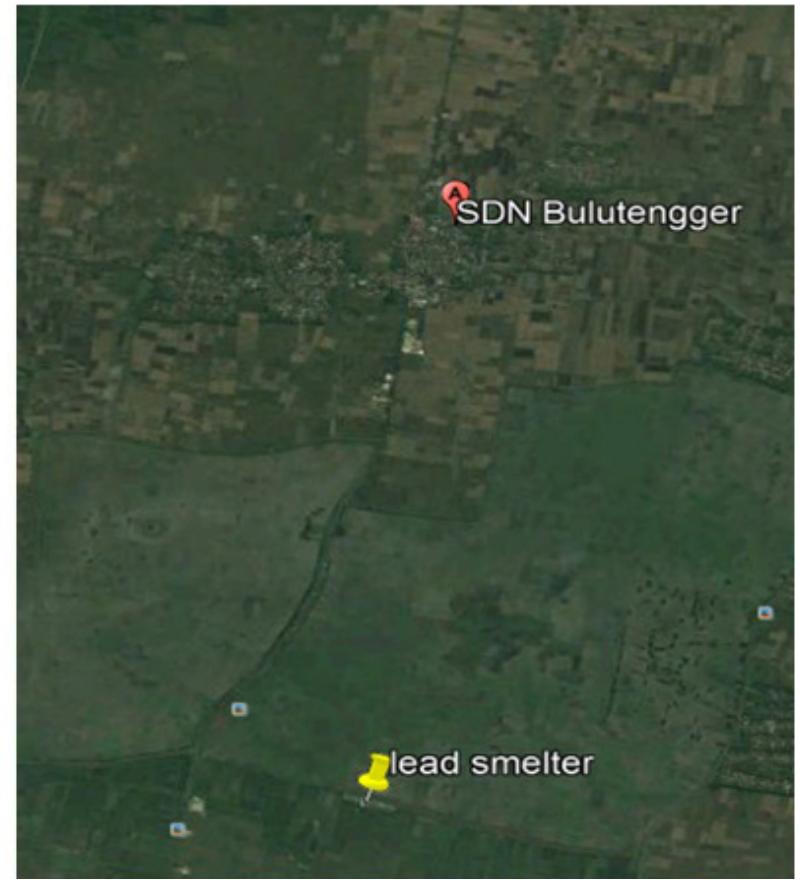

Gambar 5. Lokasi Kawasan Home Industry Peleburan Aki Bekas di Kabupaten Lamongan

uji darah dan peralatan Lead Care yang digunakan untuk mengukur timbel dalam darah (Lead Care sudah dikalibrasi terlebih dahulu);

e. Anak-anak berbaris melakukan pencucian tangan, pengukuran tinggi badan dan berat badan, dan antri untuk dilakukan pengambilan contoh uji darah;

f. Contoh uji darah diambil pada ujung jari anak-anak dan dilakukan pengukuran kadar timbel;

g. Pengambilan contoh uji dilakukan oleh dokter dan petugas dari Puskesmas yang sudah ditunjuk.

\section{Cara Kerja}

Metode analisis timbel dalam darah dilakukan dengan anodic stripping voltameter yang telah dikembangkan oleh Cooperative Research and Development Agreement dengan CDC-USA, sesuai dengan manual alat Lead Care Portable 
Analyzer (ESA Laboratories, Chelmsford, MA, USA) [12].

Sampel darah yang akan diambil adalah darah perifer melalui ujung jari tangan. Ujung jari tangan ditusuk dengan Tenderlett lancet sekali pakai yang steril. Sekitar $50 \mu 1$ (4 tetes) darah yang keluar dari ujung jari dikumpulkan pada tabung kapiler untuk analisis timbel. Setelah darah diambil, ujung jari tersebut ditutup dengan plester luka (band aid).

Prosedur analisis tersebut mencakup peletakan sampel darah ke dalam tabung reagent dan memberikan peluang pada sampel darah tersebut untuk berada dalam tabung selama 1 sampai 2 menit, yang kemudian dimasukkan ke dalam alat ukur elektroda Lead Care. Hasil analisis pada elektroda Lead Care bisa dibaca sekitar 3 menit kemudian.

Sampel darah dianalisa kadar timbel di suatu ruangan yang berpendingin. Hal ini dilakukan untuk mengurangi kontaminasi lingkungan dari tempat pengambilan, Hampir semua sampel darah dianalisa pada hari sampel tersebut diambil. Sampel darah yang sudah dianalisa beserta yaitu jarum, tabung darah, kain kasa dan sarung tangan yang sudah digunakan dimusnahkan.

\section{HASIL DAN PEMBAHASAN}

\section{Hasil Analisis Sampel Darah}

Hasil analisis terhadap 60 sampel darah responden siswa MI Baitussa' adah pada tahun 2015 berkisar antara $11,8-65 \mu \mathrm{g} / \mathrm{dL}$. Terdapat 6 data hasil analisis yang nilainya lebih tinggi dari nilai ambang deteksi maksimum instrumen lead care analyzer yaitu di atas $65 \mu \mathrm{g} / \mathrm{dL}$. Data tersebut tidak dapat diolah secara statistik karena tidak dapat dipastikan besaran nilainya. Secara umum, keseluruhan data tersebut menunjukkan bahwa konsentrasi timbel dalam darah responden jauh lebih tinggi daripada nilai rujukan $\mathrm{CDC}$ yaitu 5 $\mu \mathrm{g} / \mathrm{dL}[2]$.

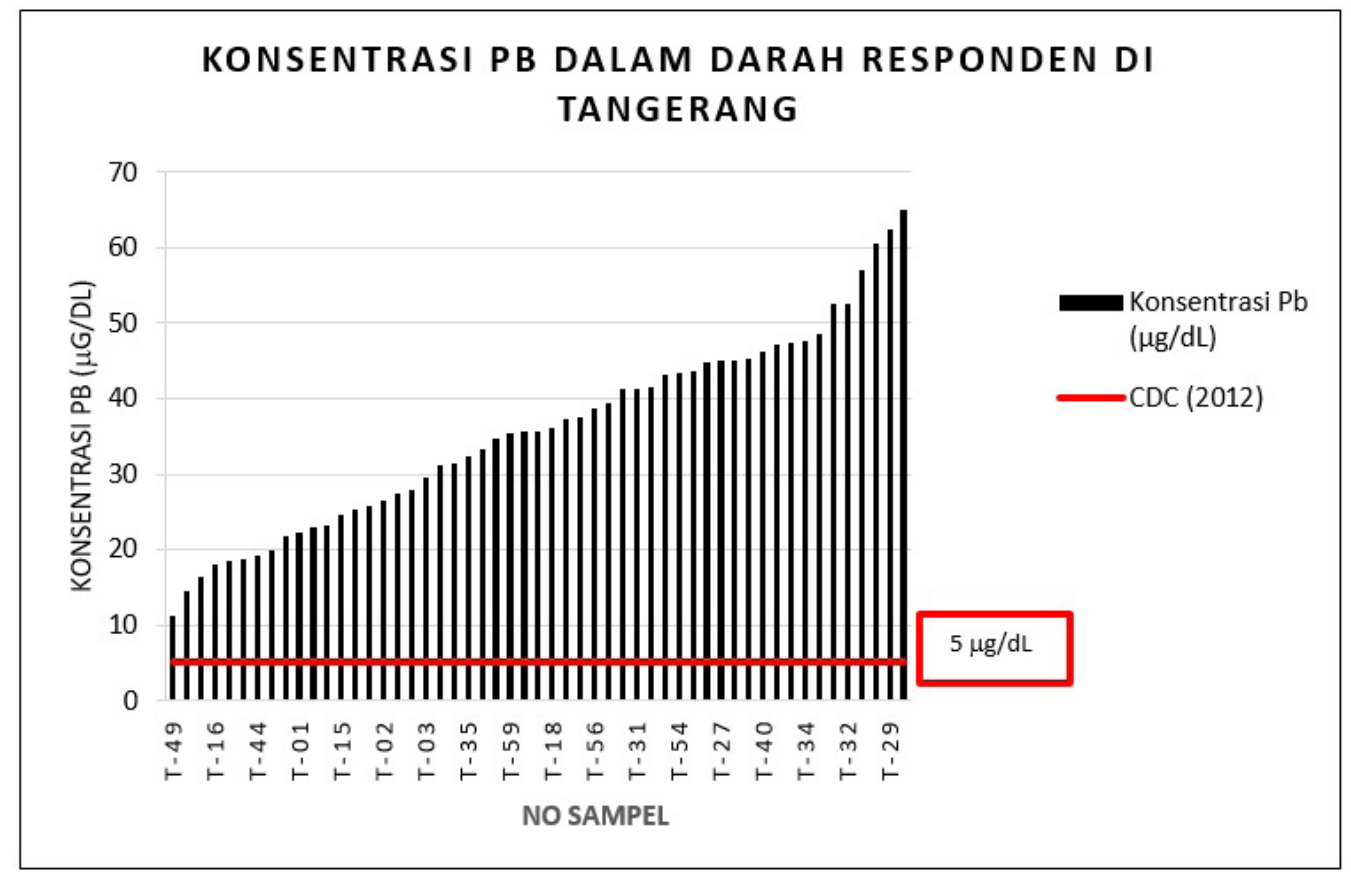

Grafik 1. Hasil Pengukuran Timbel dalam Darah Anak-Anak di Tangerang Tahun 2015 
Grafik 1 menyajikan hasil pengukuran timbel dalam darah anak-anak di lokasi penelitian Kabupaten Tangerang. Seluruh contoh uji darah siswa mengandung timbel dengan konsentrasi di atas nilai rujukan timbel dalam darah anak-anak yang ditetapkan CDC yaitu $5 \mu \mathrm{g} / \mathrm{dL}$. Nilai minimum BLL pada contoh uji yaitu $10,3 \mu \mathrm{g} / \mathrm{dL}$, sementara nilai maksimum konsentrasi timbel yang terdeteksi dalam sampel tidak dapat dipastikan nilainya karena melebih limit deteksi dari instrumen lead care analyzer yaitu sebesar $65 \mu \mathrm{g}$ / dL. Hasil penelitian ini memperkuat hasil penelitian sebelumnya yang dilakukan oleh Pusarpedal-KLH dengan BATAN bahwa timbel di udara di Kabupaten Tangerang lebih tinggi dibandingkan kota lainnya, sumber polutan timbel berasal dari industri peleburan aki bekas [6], serta hasil penelitian FKMUI kerjasama dengan Japan International Cooperation Agency (JICA) dan KLH bahwa timbel di dalam darah anak-anak di Tangerang lebih tinggi dibandingkan timbel dalam darah anak-anak di kota lainnya termasuk Jakarta [7].

Hasil analisis timbel dalam darah anak-anak SDN Bulu Tengger Lamongan, Jawa Timur tahun 2015 berkisar antara $5-30,8 \mu \mathrm{g} / \mathrm{dL}$. Hal ini pun menunjukkan kadar timbel dalam darah anak - anak tersebut diatas nilai rujukan CDC. Grafik 2 menyajikan hasil pengukuran timbel dalam darah anak-anak di lokasi penelitian Kabupaten Lamongan, Jawa Timur.

Hasil pengukuran BLL 69 responden menunjukkan nilai BLL bervariasi di atas $5 \mu \mathrm{g} /$ dL. Nilai minimum BLL pada sampel yaitu 5 $\mu \mathrm{g} / \mathrm{dL}$, dan nilai maksimum konsentrasi timbel yang terdeteksi dalam sampel yaitu $30,8 \mu \mathrm{g} /$ $\mathrm{dL}$, sehingga rerata nilai BLL pada responden $11,8 \mu \mathrm{g} / \mathrm{dL}$.

Hasil pengukuran BLL di daerah Tangerang menunjukkan nilai yang sangat tinggi hingga lebih dari 10 kali lipat nilai rujukan. Sementara

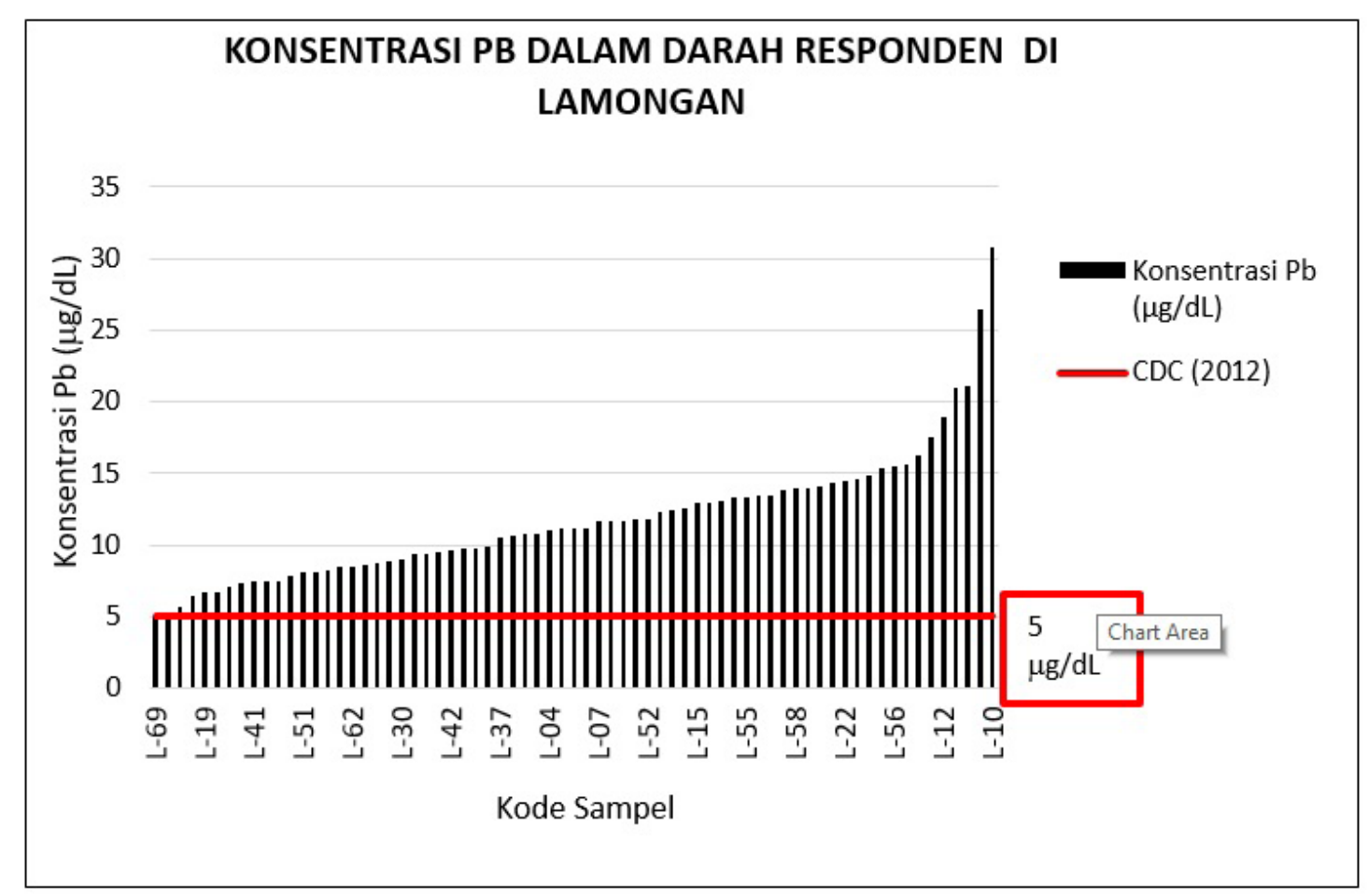

Grafik 2. Hasil Pengukuran Timbel dalam Darah Anak-Anak di Lamongan tahun 2015 
hasil pengukuran BLL di daerah Lamongan pun berada di atas nilai rujukan walaupun tidak sebesar BLL siswa di Tangerang. Hal ini dapat dipengaruhi oleh lokasi sampling yang berada dalam radius $\pm 1 \mathrm{~km}$ dari kawasan industri. Dalam kawasan industri Manis Jaya, terdapat pabrik yang diduga menggunakan timbel sebagai bahan baku dalam proses produksinya seperti pabrik peleburan aki bekas. Khusus untuk pabrik peleburan aki bekas, pabrik ini merupakan salah satu dari tiga pabrik peleburan aki bekas di Indonesia yang telah mendapatkan izin pemanfaatan limbah bahan berbahaya dan beracun (B3) dan telah beroperasi secara penuh sejak tahun 1987 dengan kapasitas produksi 96.000 ton per tahun (data tahun 2016) [8]. Di samping itu, di wilayah sekitar kawasan industri dan sekolah tidak terdapat banyak pepohonan serta merupakan wilayah yang padat penduduk. Kurangnya penghijauan di sekitar lokasi diketahui berpengaruh terhadap absorbsi polutan timbel. Penanaman beberapa jenis pohon yang diketahui dapat menyerap logam timbel di udara dapat meminimalisasi paparan timbel [9].

Sementara itu, hasil pengukuran BLL terhadap responden siswa SDN Bulu Tengger menunjukkan nilai lebih rendah dibandingkan dengan nilai pengukuran di Tangerang. Hal ini dibuktikan dengan uji t untuk melihat apakah dua set data kadar BLL responden di Tangerang berbeda nyata dengan data kadar BLL responden di Lamongan.

Dengan $p$ value lebih kecil dari nilai alpha $(0,05)$ maka disimpulkan bahwa data hasil pengukuran BLL responden di wilayah Tangerang dan Lamongan berbeda nyata dengan nilai rata-rata BLL responden wilayah Tangerang lebih tinggi daripada nilai BLL responden wilayah Lamongan.

Hal ini berkaitan dengan lokasi sampling pengukuran BLL pada siswa SDN Bulu Tengger Lamongan yang berada di tengah perkampungan dalam radius $\pm 3.5 \mathrm{~km}$ dari home industry peleburan aki bekas. Home industry peleburan aki bekas belum beroperasi secara penuh dikarenakan permasalahan izin. Secara teknologi, teknik peleburan aki disana masih menggunakan cara-cara tradisional dengan tungku peleburan dan bahan bakar kayu. Di samping itu, lokasi peleburan aki bekas merupakan area persawahan dan ruang terbuka hijau sehingga emisi partikulat dari kegiatan peleburan aki bekas sebagian dapat terserap [10].

Tabel 1. Hasil Perhitungan Uji t Kadar BLL di Tangerang dan Lamongan

\begin{tabular}{lrr}
\hline & Tangerang & Lamongan \\
\hline Mean & 35.75471698 & 11.76521739 \\
Variance & 167.7548331 & 20.82289003 \\
Observations & 53 & 69 \\
Hypothesized Mean Difference & 0 & \\
df & 62 & \\
t Stat & 12.88387087 & \\
P $(T<=$ t) two-tail & $3.45874 \mathrm{E}-19$ & \\
t Critical two-tail & 1.998971517 & \\
\hline
\end{tabular}

t-Test: Two-Sample Assuming Unequal Variances $(\bar{\alpha}=0,05)$ 

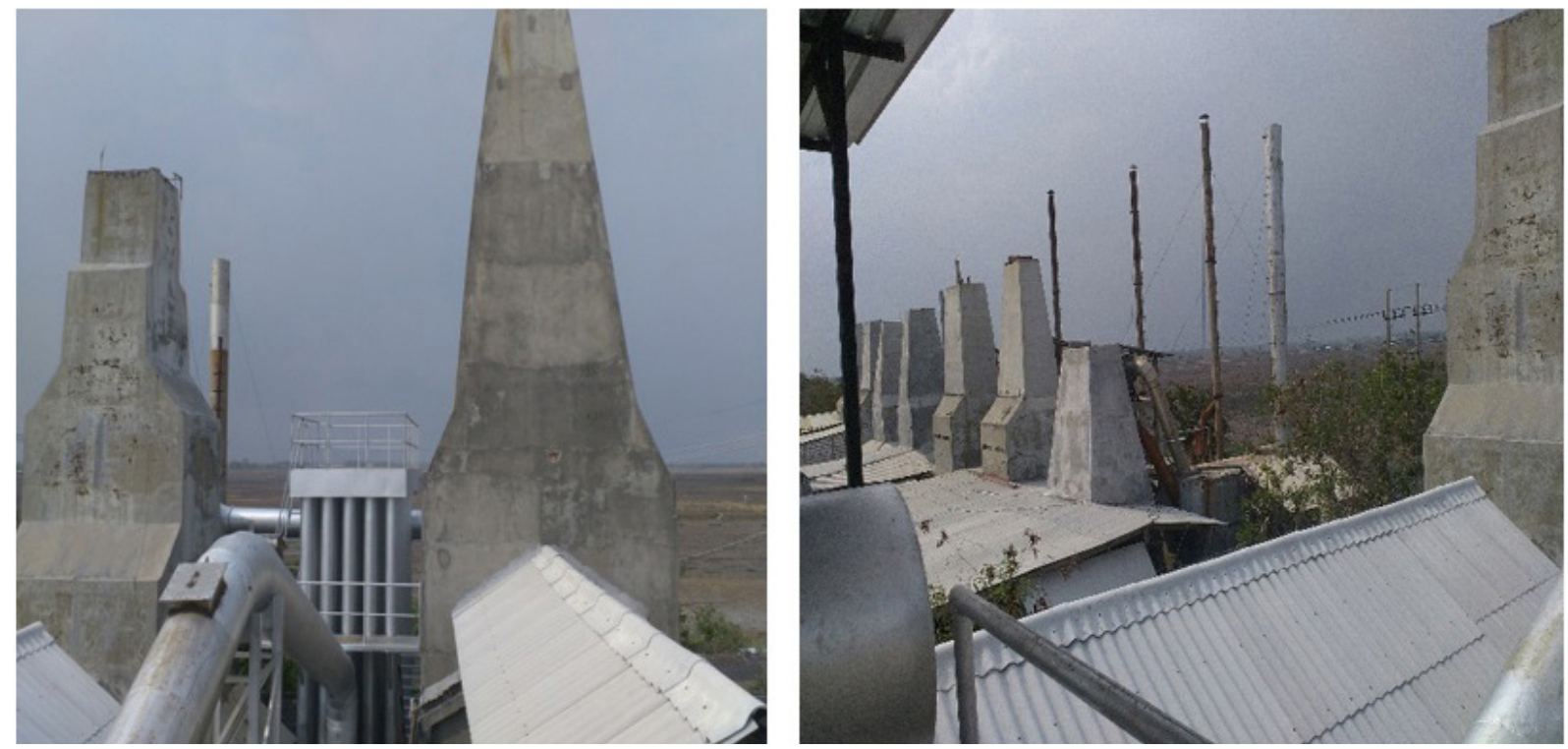

Gambar 6. Lokasi Peleburan Aki Bekas di Kelurahan Bulu Tengger, Lamongan, Jawa Timur

\section{SIMPULAN}

Kadar timbel dalam darah anak-anak sekolah di wilayah sekitar peleburan aki bekas di Kabupaten Tangerang dan Lamongan ratarata lebih tinggi dari nilai rujukan yang ditetapkan CDC yaitu $5 \mu \mathrm{g} / \mathrm{dL}$. Nilai ratarata BLL responden wilayah Tangerang lebih tinggi 7 kali dari nilai rujukan CDC. Nilai BLL responden di wilayah Tangerang lebih tinggi dari nilai BLL responden di wilayah Lamongan. Hal ini dapat disebabkan oleh kondisi sekitar peleburan aki bekas di Tangerang merupakan pemukiman padat penduduk dengan jumlah pepohonan yang minim, selain itu pabrik peleburan aki bekas di Tangerang telah beroperasi penuh sejak 1987. Sementara pada pabrik peleburan aki bekas di wilayah Lamongan, merupakan pabrik yang relatif baru dan belum beroperasi penuh terkait permasalahan izin dan di sekeliling pabrik tersebut merupakan kawasan persawahan dengan pepohonan yang masih cukup banyak.

\section{SARAN}

Melihat tingginya nilai BLL responden terutama di wilayah Tangerang, diperlukan respon mitigasi yang tepat untuk meminimalkan efek kesehatan kepada masyarakat di sekitar peleburan aki bekas. Penanaman pohon di sekitar lokasi pabrik perlu digalakkan sehingga dapat menyerap logam $\mathrm{Pb}$ dalam udara.

Di samping itu, kepada masyarakat yang tinggal di sekitar lokasi pabrik dapat diberikan suplementasi kalsium untuk menghasilkan efek khelat terhadap timbel yang masuk ke dalam tubuh masyarakat yang terpapar [11].

\section{DAFTAR PUSTAKA}

(1) Vest, Heino.2002. Fundamentals of the Recycling of Lead-Acid Batteries

(2) www.who.org. 2017. WHO Lead poisoning health

(3) www.epa.gov/roe.2017. Blood Lead. Report on the Environment 
(4) Chen L, et al. 2012. Lead exposure assessment from study near a leadacid battery factory in China. Sci Total Environ. 429: 191-198.

(5) Amber L. Beckley, Avshalom Caspi, et al. 2017. Association of Childhood Blood Lead Levels With Criminal Offending. doi:10.1001/ jamapediatrics.2017.4005 Author Affiliations: Department of Psychology and Neuroscience, Duke University, Durham

(6) Santoso, Muhayatun, et al.2011. Preliminary study of the sources of ambient air pollution in Serpong, Indonesia, Atmospheric Pollution Research 2 190-196

(7) JICA, Environmental impact Management Agency (Bapedal).1997. The Study on The Integrated Air Quality Management for Jakarta Metropolitan Area,

(8) Buletin Aplindo.2016. Industri Timah Hitam Kekurangan Bahan Baku
(9) Patel, K. S., Sharma, R., et al .2015. Heavy Metal Contamination of Tree Leaves. American Journal of Analytical Chemistry,6,687- 69

(10) Tangahu VB, et al. 2011. A Review on Heavy Metals (As, $\mathrm{Pb}$, and $\mathrm{Hg}$ ) Uptake by Plants through Phytoremediation. International Journal of Chemical Engineering Volume 2011 (2011), Article ID 939161, 31 pages

(11) h t t p : / / d x . d o i . org/10.1155/2011/939161

(12) Swaran J.S. Flora,Pachauri, Vidhu. 2010. Chelation in Metal Intoxication. Int. J. Environ. Res. Public Health, 7(7), 2745-2788; doi:10.3390/ ijerph 7072745

(13) Lead Care Portable Analyzer and Reagen Kit Manual.ESA Laboratories, Chelmsford, MA, USA

(14) Budiyono, et al. 2016. Korelasi Timbal dalam Darah dan Tingkat Kecerdasan (Majemuk) Siswa Sekolah Dasar di Sekitar Peleburan Aki Bekas di Kabupaten Tangerang dan Kabupaten Lamongan. Jurnal Ecolab https://doi. org/10.20886/jklh.2016.10.1.41-47 